\title{
The Body Weight Changes and Gut Morphometry of Clarias gariepinus juveniles on Feeds Supplemented with Walnut (Tetracarpidium conophorum) Leaf and Onion (Allium cepa) Bulb Residues
}

\author{
Cambios de Peso Corporal y Morfometría Intestinal en Clarias gariepinus juveniles \\ por Alimentos Suplementados con Hojas de Nogal (Tetracarpidium conophorum) \\ y Residuos de Bulbo de Cebolla (Allium cepa) \\ "Bello, O. S.; ${ }^{*}$ Emikpe, B. O. \& * Olaifa, F. E.
}

BELLO, O. S.; EMIKPE, B. O. \& OLAIFA, F. E. The body weight changes and gut morphometry of Clarias gariepinus juveniles on feeds supplemented with walnut (Tetracarpidium conophorum) leaf and onion (Allium cepa) bulb residues. Int. J. Morphol., 30(1):253$257,2012$.

SUMMARY: This experiment was conducted to evaluate the effects of walnut (T. conophorum) leaf and onion (A. cepa) bulb on the gut morphometry of Clarias gariepinus towards elucidating its mechanism of growth promotion. Twenty Clarias gariepinus juveniles $(7.39 \pm 0.29 \mathrm{~g}$ / fish) were allocated to nine treatments, with three replicates each. Nine experimental diets were formulated at $40 \%$ crude protein representing different level of walnut leaf and onion bulb $(0.5 \%, 1.0 \%, 1.5 \%$ and $2.0 \%)$ respectively and the control diet was free from walnut leaf and onion bulb and were fed twice daily at $3 \%$ body weight for 12 weeks. Growth indices like Mean Weight Gain (MWG), Specific Growth Rate (SGR), Feed Intake (FI) and Feed Conversion Ratio (FCR) were measured. Gut morphormetry such as villi length, villi width and cryptal depth were investigated. Data were analyzed using linear regression, descriptive statistics and ANOVA at $\mathrm{p}=0.05$. Results showed that weight gain and specific growth rate of Clarias gariepinus increased with increasing level of walnut leaf and onion bulb residues. The highest weight gain $(53.81 \pm 5.85)$, specific growth rate $(1.09 \pm 0.11)$, feed conversion ratio $(2.16 \pm 0.02)$ was observed with $1.5 \%$ inclusions of walnut leaf residue diets. Although, FCR and SGR were not significantly different ( $>0.05)$ among the treatments, the treated groups had better area of absorption and cryptal depth compared to the control. Treatment with $1.5 \%$ inclusion of walnut leaf residue recorded highest villi length and villi width and treatment with $1.5 \%$ inclusion of onion bulb recorded highest cryptal depth $(30.00 \pm 0.00)$. These results indicate that using walnut leaf and onion bulb as a supplement in plant - based diets may be useful in improving feed acceptability and growth performance of cultured C. gariepinus fed low cost, plant - based diets and it was concluded that walnut (T. conophorum) leaf at $1.5 \%$ inclusion in the diet of Clarias gariepinus improved body weight gain, feed conversion ratio by increasing the absorptive capacity through increased villi length, villi width and cryptal depth.

KEY WORDS: Onion bulb; Walnut leaf; Clarias gariepinus; Growth; Morphometry.

\section{INTRODUCTION}

Aquaculture has evolved as the fastest growing food - producing sector and developed as important component in food security (Ibrahem et al., 2010). In fish culture, nutrition plays an important role in the maintenance of a healthy and marketable product. Therefore, uses of functional feed are novel to the aquaculture industry. Clarias gariepinus is an economically important cultured fish species in Nigeria. There are a large number of feed additives available to improve fish growth performance. Some of these additives used in feed mill are chemical products especially hormones and antibiotics which may cause unfavourable side effects. To keep a sustainable growth pattern and health management, strategies must go beyond antibiotics and chemotherapeutics, which create resistant bacteria and immunosuppression in the host (Panigrahi \& Azad, 2007).

Using plants immunostimulants seems to be attractive alternative to enhance growth as a growth promoter. World Health Organization encourages using of medicinal herbs and plants to substitute or minimize the use of chemicals

\footnotetext{
* Department of Wildlife and Fisheries, University of Ibadan, Ibadan, Nigeria.

** Department of Veterinary Medicine, University of Ibadan, Ibadan, Nigeria.
} 
through the global trend to go back to the nature. Attempts to use the natural materials such as medicinal plants could be widely accepted as feed additives to enhance efficiency of feed utilization and animal productive performance (Mohamed et al., 2003). At present the scientists are working to improve feed efficiency and growth rate of livestock using useful herbs (Banyapraphatsara, 2007) and immunostimulants have been effective in enhancing growth in Oreochromis niloticus (Shalaby et al., 2006).

Some plants were found to have natural effects, for example, tonics, anti-parasitic, anti-bacterial, stimulant, carminative, antifungal, anti-microbial and antiseptic (ElEmary, 1993; Soliman et al., 1995). As antibiotics, plant extracts could control and limit the growth and colonization of numerous pathogenic and non-pathogenic species of bacteria in the gut. Walnut leaf and onion bulb as plant immunostimulants can be used as a growth promoter and health management but the mechanism of action of walnut (T. conophorum) leaf and onion (A. cepa) bulb as a growth promoter is yet to be adequately researched. It was considered that walnut (T. conophorum) leaf and onion $(A$. cepa) bulb could have the ability to improve absorptive capacity of the intestine via structural alteration. Since the gastrointestinal tract function include the digestion and absorption of nutrients into the body system. This present study was therefore aimed to investigate the effect of walnut (T. conophorum) leaf and onion (A. cepa) bulb on the gut morphometry of Clarias gariepinus.

\section{MATERIAL AND METHOD}

Plant collection and identification, Onion bulbs were purchased from Bodija market in Ibadan, Nigeria. Walnut leaf was obtained from a farm at Oka -Akoko, Nigeria. They were authenticated at the herbarium of the Forestry Research Institute of Nigeria (FRIN), Ibadan, where a voucher specimen was deposited under FHI 107515.

\section{Preparation and extraction of plant materials}

Onion extraction. The onions bulbs were washed with distilled water and allowed to air dry at ambient temperature $\left(25^{\circ} \mathrm{C}\right)$ for one hour. The dry outer coverings of the onions were manually peeled off, washed and extracted as described by Azu \& Onyeagba, (2007). 200g of the fresh onion bulbs were blended into fine powder and soaked in $100 \mathrm{ml}$ of $95 \%$ ethanol for 24 hours. The pulp obtained was left in a clean, sterile glass container, shaken vigorously to allow for proper extraction, filtered using a sterile muslin cloth after which the residue was obtained, air-dried and stored $\left(4^{\circ} \mathrm{C}\right)$ until required.
Walnut leaf extraction. The extraction was as described by Ajaiyeoba \& Fadare (2006). The air - dried walnut leaf were ground with a hammer mill to fine powder. $200 \mathrm{~g}$ of the powder of walnut leaves was soaked in $100 \mathrm{ml}$ of $80 \%$ methanol for 72 hours. Walnut leaf were properly mixed with methanol, filtered using a sterile muslin cloth after which the extract was obtained, air - dried and stored at $\left(25^{\circ} \mathrm{C}\right)$ until required.

Experimental system. The experiment was carried out in twenty seven experimental tanks $(50 \times 34 \times 27 \mathrm{~cm})$ for 12 weeks in the Fisheries Laboratory, Department of Wildlife and Fisheries Management, University of Ibadan, Nigeria. The water level in each tank was maintained at volume of 35litres throughout the experimental period. Water in each tank was replaced every three (3) days throughout the period of the experiment to maintain relatively uniform physiochemical parameters and also to prevent fouling that may resulting from feed residues. The source of water was from the University of Ibadan (U.I) water station and each experimental tank was well aerated using air stone and aerator pumps (Lawson, 1995).

Experimental procedure and feeding trials. Each treatment had three replicates, 20 fish per replicate with mean initial body weight of $7.39 \pm 0.29 \mathrm{~g}$ and uniform- sized fish was selected from 700 juveniles. Weighed and distributed in experimental tank. The fish were acclimated for fourteen days in glass aquaria before the experiment. The experiment lasted for 12 weeks during which the fish was fed at $3 \%$ body weight daily. The diet per day was divided into two; $1.5 \%$ given in the morning by $8.00-9.00$ am and $1.5 \%$ in the evening by $5.00 \mathrm{pm}$. Measurement of the weight changes was performed forthnightly and the feeding rate adjusted forthnightly according to the new body weight.

Preparation of experimental diets. The mean proximate composition of the experimental diet was $40.0 \%$ crude protein, $15.9 \%$ ether extract, $15.7 \%$ ash, $7.4 \%$ moisture, and $20.9 \%$ NFE. Nine experimental diets were prepared by incorporating walnut leaf and onion bulb residues at the following inclusion levels; 0 (control), $0.5 \%, 1.0 \%, 1.5 \%$ and $2.0 \%$ respectively. Feed ingredients such as fishmeal, soybean, maize, starch, vegetable oil, Di calcium phosphate (DCP), salt and vitamin- mineral premix were added and the dry ingredients were mixed thoroughly in a mixer. Water was added and the resulting dough was pelletted, the pelletted diets were sun -dried, and stored in airtight containers at room temperature to prevent mycotoxin formation until required.

\section{Biological evaluation}

- Weight gain = final body weight - initial body weight

- Feed conversion ratio $(\mathrm{FCR})=$ Dry weight of feed fed $(\mathrm{g}) /$ Fish weight gain $(\mathrm{g})$ 
- Feed intake $=$ Total feed consumed/No of fish stocked - Specific growth rate $(\mathrm{SGR})=100$ (loge final body weightloge initial body weight)/Time (days)

Histomorphometric evaluation. The sections of the intestine of $C$. gariepinus were routinely prepared in histopathology Laboratory of Department of Veterinary Pathology, University of Ibadan, Nigeria. Measurements of cryptal depth, villi length and width were taken using microscope with a micrometer rule as described by Spadoni et al. (2005) and Eyarefe et al. (2008). Four different villi were measured in each slide per parameter, recorded and an average values calculated.

Statistical analysis. Growth performance and gut morphomentry (villi length and width, cryptal depth) resulting from the experiment were subjected to one-way analysis of variance (ANOVA) and linear regression using SPSS (Statistical Package for Social Sciences 2006 version 15.0). Duncan multiple range test was used to compare differences among individual means.

\section{RESULTS}

In Table I we can show the growth performance of C. gariepinus fed onion bulb and walnut leaf residues - based diets for twelve weeks. In Table II are summarized the changes in villi length, villi width and cryptal depth of $C$. gariepinus fed onion bulb and walnut leaf residues for twelve weeks.

The regression relationship between weight gain and surface area of absorption (villi length and width) of walnut leaf and onion bulb residues based diets revealed that the linear regression coefficient of walnut leaf and onion bulb treatment were 0.9877 and 0.7758 respectively of the surface area of absorption. The result showed that walnut leaf diets positively correlated with the weight gain when compared to the onion bulb treatment.

Table I. Growth performance of $C$. gariepinus fed onion bulb and walnut leaf residues - based diets for 12 weeks. Key: Mean followed by the same letter is not significantly different $(\mathrm{p}>0.05)$

\begin{tabular}{lcccc}
\hline Parameters & Feed intake $(\mathrm{g})$ & Specif ic growth rate $(\mathrm{g})$ & Body weight gain $(\mathrm{g})$ & Feed Conversion Ratio (FCR) \\
\hline Control & $2397.00 \pm 2.82 \mathrm{~g}$ & $1.02 \pm 0.02^{\mathrm{a}}$ & $45.44 \pm 2.18 \mathrm{a}$ & $2.64 \pm 0.03 \mathrm{a}$ \\
OB2 & $2384.50 \pm 0.00^{\mathrm{f}}$ & $1.04 \pm 0.05^{\mathrm{a}}$ & $47.76 \pm 4.68^{\mathrm{b}}$ & $2.50 \pm 0.01 \mathrm{a}$ \\
OB3 & $2458.00 \pm 0.82 \mathrm{~h}$ & $1.05 \pm 0.01^{\mathrm{a}}$ & $48.08 \pm 0.92 \mathrm{a}^{\mathrm{b}}$ & $2.56 \pm 0.02 \mathrm{a}$ \\
OB4 & $2529.80 \pm 0.00 \mathrm{a}$ & $1.05 \pm 0.04^{\mathrm{a}}$ & $49.31 \pm 4.61 \mathrm{a}^{\mathrm{b}}$ & $2.57 \pm 0.00 \mathrm{a}$ \\
OB5 & $2309.00 \pm 2.82 \mathrm{~d}$ & $1.02 \pm 0.00^{\mathrm{a}}$ & $45.83 \pm 0.04 \mathrm{a}$ & $2.52 \pm 0.01 \mathrm{a}$ \\
WL6 & $2279.50 \pm 0.09^{\mathrm{c}}$ & $1.02 \pm 0.04^{\mathrm{a}}$ & $46.29 \pm 4.18 \mathrm{a}^{\mathrm{b}}$ & $2.46 \pm 0.00 \mathrm{a}$ \\
WL7 & $2223.30 \pm 0.00 \mathrm{~b}$ & $1.04 \pm 0.13^{\mathrm{a}}$ & $49.41 \pm 5.2 \mathrm{a}^{\mathrm{b}}$ & $2.25 \pm 0.01 \mathrm{a}$ \\
WL8 & $2325.50 \pm 1.00^{\mathrm{e}}$ & $1.09 \pm 0.11^{\mathrm{a}}$ & $53.81 \pm 5.85 \mathrm{~b}$ & $2.16 \pm 0.02 \mathrm{a}$ \\
WL9 & $2195.00 \pm 0.00^{\mathrm{a}}$ & $1.02 \pm 0.08^{\mathrm{a}}$ & $45.69 \pm 7.96 \mathrm{a}$ & $2.40 \pm 0.03 \mathrm{a}$ \\
\hline
\end{tabular}

Table II. Changes in villi length, villi width and cryptal depth of $C$. gariepinus fed onion bulb and walnut leaf residues for 12 weeks. Key: Mean followed by the same letter is not significantly different ( $p>0.05)$. Key: Mean followed by the same letter is not significantly different $(\mathrm{p}>0.05)$

\begin{tabular}{lcccc}
\hline Parameters & Villi length $(\mu \mathrm{m})$ & Villi width $(\mu \mathrm{m})$ & $\begin{array}{c}\text { Area of absorption }(\text { villi } \\
\text { length x villi width })\left(\mu \mathrm{m}^{2}\right)\end{array}$ & Cryptal depth $(\mu \mathrm{m})$ \\
\hline Control & $69.00 \pm 1.15^{\mathrm{c}}$ & $10.33 \pm 1.53 \mathrm{a}^{\mathrm{b}}$ & $712.77 \pm 0.00 \mathrm{c}$ & $19.00 \pm 1.41^{\mathrm{bc}}$ \\
OB2 & $69.50 \pm 0.00^{\mathrm{c}}$ & $10.85 \pm 0.10 \mathrm{ab}^{\mathrm{c}}$ & $754.08 \pm 2.82^{\mathrm{d}}$ & $16.00 \pm 0.00^{\mathrm{ab}}$ \\
OB3 & $69.00 \pm 0.04^{\mathrm{c}}$ & $13.50 \pm 1.50 \mathrm{~d}^{\mathrm{ef}}$ & $931.50 \pm 0.00^{\mathrm{g}}$ & $15.60 \pm 0.00^{\mathrm{ab}}$ \\
OB4 & $67.50 \pm 0.05^{\mathrm{c}}$ & $16.00 \pm 1.73 \mathrm{~g}$ & $1080.00 \pm 2.82^{\mathrm{h}}$ & $30.00 \pm 0.00^{\mathrm{d}}$ \\
OB5 & $54.00 \pm 1.41^{\mathrm{a}}$ & $10.00 \pm 0.00^{\mathrm{a}}$ & $540.00 \pm 0.00 \mathrm{a}$ & $20.00 \pm 0.00^{\mathrm{c}}$ \\
WL6 & $61.25 \pm 2.50 \mathrm{~b}$ & $12.50 \pm 1.32 \mathrm{~cd}^{\mathrm{e}}$ & $765.63 \pm 0.00 \mathrm{e}$ & $18.00 \pm 0.82^{\mathrm{bc}}$ \\
WL7 & $58.00 \pm 2.40 \mathrm{a}^{\mathrm{b}}$ & $15.00 \pm 0.00^{\text {fg }}$ & $870.00 \pm 2.82 \mathrm{f}$ & $13.00 \pm 0.02^{\mathrm{a}}$ \\
WL8 & $78.75 \pm 0.96 \mathrm{~d}$ & $14.00 \pm 1.00^{\mathrm{ef}}$ & $1102.50 \pm 2.80 \mathrm{i}$ & $20.00 \pm 0.00^{\mathrm{c}}$ \\
WL9 & $58.00 \pm 0.00 \mathrm{a}^{\mathrm{b}}$ & $12.00 \pm 0.00 \mathrm{~b}^{\mathrm{cd}}$ & $696.00 \pm 0.00^{\mathrm{b}}$ & $20.00 \pm 0.00^{\mathrm{c}}$ \\
\hline
\end{tabular}




\section{DISCUSSION}

There was a general increase in weight gain in the course of the experiment with the highest growth performance observed in fish fed on $1.5 \%$ walnut leaf $(53.81 \pm 5.85 \mathrm{~g})$ and $1.5 \%$ onion bulb $(49.31 \pm 04.61 \mathrm{~g})$. Also, treatment with $1.5 \%$ walnut leaf recorded the highest specific growth rate $(1.09 \pm 0.11)$ and the control recorded (1.02 \pm 0.02$)$. The higher values obtained in the treated groups could be due to the presence of growth stimulants or constituents in onion bulb (flavonoids and thiosulfinates) and walnut leaves (alkaloids and tannins). The result of this current study is in accord with the report of Abou- Zeid (2002) which showed that Allium sativum supplementation positively affected $O$. niloticus biomass and specific growth rate (SGR). The result of the experiment also showed that the treated groups had better Feed Conversion Ratio (FCR) compared to the control with WL8 recorded the highest value of feed conversion ratio of $2.16 \pm 0.02 \mathrm{~g}$ and there were no significantly difference ( $\mathrm{p}>$ $0.05)$ in FCR among the treatments. The result of this finding is also similar to the report of Abd El-Rhman (2009) and Abd El-Rhman et al. which revealed that the addition of Propolisethanolic-extract and crude propolis (1\%) to artificial basal diet with (30\% crude protein) increased the FCR, FER and PER in the treated group than the control.

Gut morphometry is a tool that can be used to evaluate the absorption of nutrients in an animals and the assessment of the gut morphometry of the $C$. gariepinus fed different level of inclusions of walnut leaf and onion bulb residues - based diets showed significant values of mean villi length and width (area of absorption) $(\mathrm{p}<0.05)$ in the treated groups compared to the control. This represents an increased in the absorptive surface area of the intestine and thus an increased absorptive capacity with the resultant higher body weight gain and FCR in the treated groups compared to the control. Also, there was significant mean cryptal depth (regeneration) in the treated groups than the control, which in turn enhances digestion as cryptal cells had been reported to be responsible for secretion of the electrolytes which enhance water secretion into the intestinal lumen for the purpose of digestion (Bowen, 2011).

It could be suggested that digestibility which was enhanced in the treated groups compared to the control with highest body weight gain, percent weight gain and FCR of $53.81 \pm 5.85,727.16 \pm 1.40$ and $2.16 \pm 0.02$ in WL8 could be due to the enhanced absorptive area and the increased cryptal depth recorded which is an indication of a higher mucosal proliferation activity and greater intestinal glandular activity. The report is similar to that of Zhou et al. (2000) that higher cryptal depth revealed more efficient digestibility and absorption in ingested feed.
Although, the relationship between the treated groups revealed that the diets were better utilized and enhance growth as a result of better surface area of absorption recorded in treated groups compared to the control, this may be as a result of stimulating properties present in walnut leaf and onion bulb.

The result of gut morphometry observed in $C$. gariepinus fed with onion bulb and walnut leaf residues compared with the control further showed the benefit of walnut leaf and onion bulb in enhancing and maintaining the intestinal mucosa.

It could be inferred that walnut leaf and onion bulb have the ability to increase the digestive and absorptive capacity of the intestine of $C$. gariepinus juveniles by increasing the cryptal depth, as well as absorptive surface area of the intestine (villi length and width).

In conclusion, since walnut leaf and onion bulb are more available and relatively cheaper, it could be recommended that inclusion of $1.5 \%$ walnut leaf in the diet of $C$. gariepinus would aid fish productivity.

BELLO, O. S.; EMIKPE, B. O. \& OLAIFA, F. E. Cambios de peso corporal y morfometría intestinal en Clarias gariepinus juveniles por alimentos suplementados con hojas de nogal (Tetracarpidium conophorum) y residuos de bulbo de cebolla (Allium cepa). Int. J. Morphol., 30(1):253-257, 2012.

RESUMEN: Este estudio fue realizado para evaluar los efectos de la hoja del nogal (T. conophorum) y el bulbo de la cebolla ( $A$. сера) sobre la morfometría intestinal de Clarias gariepinus con el fin de dilucidar su mecanismo de promoción del crecimiento. Veinte Clarias gariepinus jóvenes $(7,39 \pm 0,29 \mathrm{~g} / \mathrm{pez})$ fueron asignadas a nueve tratamientos, con tres repeticiones cada uno. Nueve dietas experimentales se formularon con la proteína cruda al $40 \%$ que representan los diferentes niveles de hoja del nogal y el bulbo de la cebolla $(0,5 \%$, $1,0 \%, 1,5 \%$ y $2,0 \%$ ), respectivamente, y dieta de control libre de la hoja del nogal y el bulbo de la cebolla, que fueron alimentados dos veces al día en un 3\% del peso corporal durante 12 semanas. Fueron medidos los índices de crecimiento como aumento de peso medio (APM), tasa de crecimiento específico (TCE), consumo de alimento (CA) y el índice de conversión alimeticia (ICA). La morfometría intestinal como longitud de las vellosidades, ancho de las vellosidades y profundidad de las criptas fueron investigados. Los datos fueron analizados mediante regresión lineal, estadística descriptiva y ANOVA con un valos $\mathrm{p}=0,05$. Los resultados mostraron que el aumento de peso y la tasa de crecimiento específico de Clarias gariepinus se elevó al aumentar el nivel de la hoja de nogal y los residuos del bulbo de cebolla. La mayor ganancia de peso $(53,81 \pm 5,85)$, tasa de crecimiento específico $(1,09 \pm 0,11)$, tasa de conversión alimenticia $(2,16$ $\pm 0,02$ ) se observó con inclusiones de $1,5 \%$ de las dietas de residuos de hojas de nogal. Aunque el ICA y TCE no fueron significativamente diferentes ( $p>0,05)$ entre los tratamientos. Los grupos tratados tuvieron una mejor área de absorción y profundidad de las criptas en comparación con el control. El tratamiento con 1,5\% de inclusión de 
hojas de nogal registró la mayor longitud y ancho de las vellosidades y el tratamiento con $1,5 \%$ de inclusión de los residuos del bulbo de cebolla registró una mayor profundidad de las criptas $(30,00 \pm 0,00)$. Estos resultados indican que el uso de hojas de nogal y del bulbo de la cebolla como un suplemento en dietas basadas en vegetales pueden ser útiles en la mejora de la aceptabilidad de alimentación y crecimiento de los cultivos de C. gariepinus alimentados con bajo costo, basados en dietas vegetales. Se concluyó que la inclusión de 1,5\% de hoja del nogal (T. conophorum) en la dieta de Clarias gariepinus mejora la ganancia de peso corporal, índice de conversión alimenticia mediante el aumento de la capacidad de absorción a través de mayor longitud y ancho de las vellosidades, y la profundidad de las criptas.

PALABRAS CLAVE: Bulbo de cebolla; Hoja de nogal; Clarias gariepinus; Crecimiento; Morfometría.

\section{REFERENCES}

Abd El-Rhman, A. M.; Khattab, Y. A. \& Shalaby, A. M. Micrococcus luteus and Pseudomonas species as probiotics for promoting the growth performance and health of Nile tilapia, Oreochromis niloticus. Fish Shellfish Immunol., 27:175-80, 2009.

Abd El-Rhman, A. M. Antagonism of Aeromonas hydrophila by propolis and its effect on the performance of Nile tilapia, Oreochromis niloticus. Fish Shellfish Immunol. 27:454-9, 2009.

Abou-zeid, S. M. The effect of some medical plant on reproductive and productive performance of Nile tilapia fish. Ph. D. Thesis Cairo, Faculty of Agriculture, Cairo University, 2002. p.212.

Ajaiyeoba, E. O. \& Fadare, D. A. Antimicrobial potential of extracts and fractions of the African walnut - Tetracarpidium conophorum. Afr. J. Biotechnol., 5:2322-5, 2006.

Azu, N. C. \& Onyeagba, R. A. Antimicrobial properties of extracts of Allium cepa (Onions) and Zingiber officinale (Ginger) on Escherichia coli, Salmonella typhi, and Bacillus subtilis. Internet J Trop Med., 3(2), 2007. Available in: http://www.ispub.com:80/ journal/the-internet-journal-of-tropical-medicine/volume-3number-2/antimicrobial-properties-of-extracts-of-allium-cepaonions-and-zingiber-officinale-ginger-on-escherichia-colisalmonella-typhi-and-bacillus-subtilis.html

Bowen, R. Villi, crypts and the life cycle of small intestinal enterocytes in pathophysiology of the digestive system, 2011. Available in: http/www.vivo.colostate.edu/hbooks/pathphys/digestive/ smallgut/lifecycle.html

Bunyapraphatsara, N. Utilization of medicinal plants in animal production. $11^{\text {th }}$ International Congress. Leiden, Netherlands, Phytopharmacology, 2007.

El-Emary, N. A. Egyptian medicinal plants: An over view I. Assiut. J. Env. Stud., 2:18-9, 1993.
Eyarefe, O. D.; Emikpe, B. O. \& Arowolo, F. O. Small bowel responses to enteral honey and glutamine administration following massive small bowel resection in rabbit. Afr. J. Med. Med. Sci., 37:309-14, 2008.

Ibrahem, M. D.; Fathi, M.; Mesalhy, S. \& Abd El-Aty, A. M. Effect of dietary supplementation of insulin and vitamin $\mathrm{C}$ on the growth, haematology, innate immunity, and resistance of Nile tilapia (Oreochromis niloticus). Fish Shellfish Immunol., 29:2416, 2010.

Lawson, T. B. Fundamental of Aquaculture Engineering (Chapman and Hall 1995). New York, Chapman and Hall, 1995. pp.28-39.

Mohamed, A. H.; El-Saidy, B. \& El-Seidy, I. A. Influence of some medicinal plants supplementation: 1- On digestibility, nutritive value, rumen fermentation and some blood biochemical parameters in sheep. Egypt. J. Nutr. Feeds, 6:139-50, 2003.

Panigrahi, A. \& Azad, I. S. Microbial intervention for better fish health in aquaculture: the Indian scenario. Fish Physiol. Biochem., 33:429-40, 2007.

Shalaby, A. M.; Khattab, Y. A. \& Abdel Rahman, A. M. Effects of garlic (Allium sativum) and chloramphenicol on growth performance, physiological parameters and survival of Nile tilapia. $J$. Venom. Anim. Toxins incl. Trop. Dis., 12:172-201, 2006.

Soliman, A. Z.; Abd El-Malak, N. Y. \& Abbas, A. M. Effect of using some commercial feed additives as promoters on the performance of growing and adult rabbits. Egypt. J. App. Sci., 10:50115, 1995.

Spadoni, J. M.; Aguilar-Nascimento, J. E.; Silva, M. H.; SpadoniNeto, B.; Costa, P. A. \& Aléssio, D. M. Effects of combined use of glutamine and growth hormone in the intestinal after massive resection of the small bowel in rats. Acta Cir. Bras., 20:382-9, 2005.

Zhou, X.; Li, N. \& Li, J. S. Growth hormone stimulates a remnant small bowel epithelial cell proliferation. World J. Gastroenterol., 6:909-13, 2003.

Correspondence to:

Bello, O. S.

Department of Wildlife and Fisheries

University of Ibadan

NIGERIA

Email: belloolus@yahoo.com

Received: 03-11-2011

Accepted: 12-12-2011 